Chirurgia (2020) 115: 735-746

No. 6, November - December

Copyright@ Celsius

http://dx.doi.org/10.21614/chirurgia.115.6.735

\title{
Single Center Experience in Pancreatic Surgery
}

\author{
Cezar Stroescu', Alexandru Martiniuc ${ }^{1 *}$, Radu Poenaru', Dragos Chirita', Nicolae Boleac', lanos Pahomea ${ }^{1}$, \\ Ana Stanila', Cristina Amza', Daniela Tabacelia'², Madalina Greere ${ }^{2}$, Cristian Rosianu' ${ }^{2}$, Adelina Birceanu ${ }^{3}$, \\ Laura Popa ${ }^{4}$, Narcis Copca ${ }^{1}$
}

\author{
12nd Department of Surgery, "Sfânta Maria" Clinical Hospital Bucharest, Romania \\ 2Department of Gastroenterology, "Sfânta Maria" Clinical Hospital Bucharest, Romania \\ ${ }^{3}$ Department of Pathology, "Sfânta Maria" Clinical Hospital Bucharest, Romania \\ ${ }^{4}$ Department of Anesthesiology and Intensive Care Unit, "Sfânta Maria" Clinical Hospital Bucharest, Romania
}

*Corresponding author:

Alexandru Martiniuc MD

2nd Department of Surgery

"Sfânta Maria Clinical Hospital

"Carol Davila" University of Medicine and Pharmacy

E-mail: alex.martiniuc@gmail.com

\section{Rezumat}

Experiența unui singur centru în chirurgia pancreatică

Introducere: Prezentăm experiența departamentului nostru în chirurgia pancreatică pe o perioadă de 6 ani. De la înființare şi până în prezent, numărul de rezecții pancreatice a crescut semnificativ în fiecare an.

Metodă:S-a efectuat o analiză retrospectivă a bazei de date de la nivelul departamentului unde sunt introduşi toți pacienții cu rezecții pancreatice. Sunt prezentate atât tipurile de intervenții chirurgicale cât şi complicațiile postoperatorii, mortalitatea intraspitalicească şi la 90 de zile precum şi o analiză a supra-viețuirii în cazul rezecției pentru carcinomul ductal pancreatic.

Rezultate: In total s-au analizat 198 de pacienți, dintre care 193 cu rezecții pancreatice şi 5 pacienți la care s-a practicat ablație tumorală cu microunde. In total au fost 145 de duodenopancreatectomii, 37 de pancreatectomii distale, o pancreatectomie totală, 3 pancreatectomii distale în bloc cu rezecție de trunchi celiac (Appleby modificat) şi 7 intervenții chirurgicale specifice pentru pancreatită cronică.

Concluzii: Chirurgia pancreatică presupune morbiditate crescută chiar şi în centrele cu volum mare. Deşi experiența noastră are în general rezultate bune, acestea trebuiesc încontinuu rafinate şi îmbunătățite pentru ameliorarea morbidității şi mortalității post-operatorii.
Received: 10.10 .2020 Accepted: 08.12.2020 
Cuvinte cheie: chirurgie pancreatică, duodenopancreatectomie, pancreatectomie distala, ablație cu microunde

\begin{abstract}
Introduction: We present our department experience in pancreatic surgery over the last 6 years. From its inception the number of pancreatic resections has been continuously growing each year. Method: We performed a retrospective analysis of a prospectively maintained database where we included all the patients with pancreatic resections over the last 6 years. We present the main indication and the different types of pancreatic resections, postoperative morbidity, intrahospital and 90-day mortality and an analysis of survival for the patients with pancreatic ductal adenocarcinoma.

Results:We analyzed 198 patients, 193 with pancreatic resections and 5 patients with open surgery microwave ablation. There were 145 pancreaticoduodenectomies, 37 distal pancreatectomies, one total pancreatectomy, 3 distal pancreatectomies with celiac axis resection and 7 surgical interventions for chronic pancreatitis.

Conclusion: We presented our center's experience in pancreatic surgery with good overall results, however, there is still room for continuous improvement and refinements to achieve better shortterm outcomes, regarding postoperative morbidity and mortality.
\end{abstract}

Kew words: pancreatic surgery, pancreaticoduodenectomy, distal pancreatectomy, microwave ablation

\section{Introduction}

Over the past few decades, hepatobiliary and pancreatic surgery has evolved as its own specialty requiring advanced fellowship training and a variety of specially dedicated organizational structures with important financial implications (1).

From the first anatomical distal pancreatic resection performed by Friedrich Trendelenburg in 1882 (2) and the first pancreaticoduodenectomy performed by Codivilla in 1898 (3), important developments in preoperative diagnosis, surgical technique as well as perioperative care have been made, leading to significant decrease in mortality from the first series published by Whipple in 1946 (4). Pancreatic surgery remains one of the most challenging fields in digestive surgery and remains associated with important rates of morbidity (5).

The aim of this study was to present our departments experience in pancreatic surgery as an emerging center.

\section{Methods}

We performed a retrospective analysis at our Department of Surgery, from January 1, 2014 to October 1, 2020. From October 1, 2016 when we started to enroll patients to the national registry for pancreatic resections, the database was completed prospectively. Before the date mentioned, patients and data were introduced from hospital records.

All the patients with any type of pancreatic resection were included and also a new kind of approach - pancreatic microwave ablation (5 patients by open surgery). The primary aim for our analyses was to report the number and the variety of pancreatic surgical procedures, vascular resections and reconstructions as well as the postoperative morbidity and a survival analysis for pancreatic ductal adenocarcinoma.

Data are presented as number (percentage) for categorical variables, as mean $( \pm$ standard deviation) for continuous variables and as median (range) when specified. The post- 
operative complications, post-operative pancreatic fistula (POPH) was reported according to the updated International Study Group for Pancreatic Surgery (ISGPS) definition and grading system (6). Post-pancreatectomy hemorrhage (PPH) was defined and reported according to the 2007 ISGPS definition (7). Delayed gastric emptying (DGE) was defined and reported according to the 2007 ISGPS definition (8).

The severity of postoperative complications was assessed and reported using the ClavienDindo Classification (9). The postoperative mortality was presented as in-hospital mortality and as 90-day mortality.

The survival analyses for patients with pancreatic ductal adenocarcinoma was performed with SPSS (Statistical Packages for Social Sciences) version 20.0 software (SPSS Inc., Chicago, IL). The overall survival time was considered the time from resection to death or last follow-up (October 1, 2020).

\section{Results}

We analyzed 198 patients who underwent pancreatic surgery in our clinic from the 1st of January 2014 to the 1st of October 2020. There were 145 patients who underwent a pancreaticoduodenectomy, 37 patients with distal pancreatectomies, 2 patients with distal pancreatectomy and celiac axis resection (modified Appleby), one patient with a distal pancreatectomy with celiac trunk resection and reimplantation, one patient with total pancreatectomy (TP), 7 patients with surgical procedures for chronic pancreatitis.

Five patients were treated by open surgery pancreatic microwave ablation, 3 with locally advanced pancreatic head adenocarcinoma with neoadjuvant chemotherapy, one patient with a pancreatic stump recurrence after distal pancreatectomy and one patient with an uncinate process neuroendocrine tumor. The different types of pancreatic surgical procedures are illustrated in Table 1.

The median age of the cohort was 53 years (range 24-83 years old) and the gender distribution was $114(57,6 \%)$ males and $84(42.4 \%)$
Table 1. Types of pancreatic surgical procedure

\begin{tabular}{lr}
\hline Procedure & Patients (\%) \\
\hline Pancreaticoduodenectomies: & $145(100 \%)$ \\
- Whipple: & $29(20 \%)$ \\
- Pylorus-preserving: & $57(39.3 \%)$ \\
- Pylorus-resection: & $58(40 \%)$ \\
- Total gastrectomy & $1(0.7 \%)$ \\
\hline Distal Pancreatectomies & $40(100 \%)$ \\
- Standard distal pancreatectomy & $26(65 \%)$ \\
- Subtotal & $4(10 \%)$ \\
- Caudal pancreatectomies & $7(17,5 \%)$ \\
- Distal pancreatectomy with celiac axis resection & $2(5 \%)$ \\
(Modified Appleby) & \\
- Distal pancreatectomy with celiac axis resection & $1(2,5 \%)$ \\
and celiac trunk reimplantation & \\
\hline Total pancreatectomy & $1(100 \%)$ \\
\hline Chronic Pancreatitis surgery & $7(100 \%)$ \\
- Beger: & $2(28,6 \%)$ \\
- Berna: & $1(14,2 \%)$ \\
- Frey: & $2(28,6 \%)$ \\
- Partington-Rochelle: & $2(28,6 \%)$ \\
\hline Open Microwave ablation & $5(100 \%)$ \\
- Locally advanced pancreatic head adenocarcinoma: & $3(60 \%)$ \\
- pancreatic stump recurrence after distal pancreatectomy & $1(20 \%)$ \\
- Uncinate process neuroendocrine tumor: & $1(20 \%)$ \\
\hline
\end{tabular}

females. Patients characteristics are shown in Table 2. In order to analyze each type of procedure we divided the patients into 5 groups according to the procedure performed: pancreaticoduodenectomy (PD), distal pancreatectomy (DP), distal pancreatectomy with celiac axis resection (DP-CAR), surgery for chronic pancreatitis (CPS) and open microwave ablation (oMWA).

\section{Pancreaticoduodenectomy Group}

In our series there were 145 pancreaticoduodenectomies. The indications for resection are illustrated in Table 3. Seventy-two of pancreatic head resections were performed for pancreatic ductal adenocarcinoma. The posterior superior mesenteric artery first approach was performed in $105(72,4 \%)$ patients Fig. 1. Vascular resections were necessarily in $22(15.1 \%)$ patients.

There were 16 portal-mesenteric resections, from which 10 were segmental resections and 6 were tangential resections. For segmental resections, primary end to end anastomosis was performed in all patients. The tangential resections were reconstructed by primary suture in 3 
Table 2. Patient characteristics (total 198)

\begin{tabular}{|c|c|c|c|c|c|c|}
\hline Procedure and number of patients & $\begin{array}{c}\text { PD } \\
145\end{array}$ & $\begin{array}{l}\text { DP } \\
37\end{array}$ & $\begin{array}{c}\text { DP-CAR } \\
3\end{array}$ & $\begin{array}{c}\text { TP } \\
1\end{array}$ & $\begin{array}{c}\text { CPS } \\
7\end{array}$ & $\begin{array}{c}\text { oMWA } \\
5\end{array}$ \\
\hline \multicolumn{7}{|l|}{ Gender } \\
\hline - Male & $95(65.5 \%)$ & $12(32.5 \%)$ & 2 & 1 & 3 & 1 \\
\hline - Female & $50(34.5 \%)$ & $25(67.5 \%)$ & 1 & & 4 & 4 \\
\hline Median Age (years) & 65 & 60 & 62,6 & 71 & 57 & 61 \\
\hline \multicolumn{7}{|l|}{ Symptoms } \\
\hline - Abdominal Paine & $119(82 \%)$ & $33(89.1 \%)$ & 3 & 1 & 7 & 5 \\
\hline - Weight loss & $122(84.1 \%)$ & $18(48.6 \%)$ & 3 & 1 & 7 & 5 \\
\hline - Gastric outlet obstruction & $15(10.3 \%)$ & $3(8.1 \%)$ & 0 & 1 & 0 & 0 \\
\hline \multicolumn{7}{|l|}{ Cardiovascular comorbidities } \\
\hline - Hypertension & $83(57.2 \%)$ & $18(48.6 \%)$ & 3 & 1 & 4 & 3 \\
\hline - Ischemic cardiomyopathy & $25(17.2 \%)$ & $4(10.8 \%)$ & 1 & 0 & 1 & 1 \\
\hline - Atrial fibrillation & $10(6.8 \%)$ & 0 & 1 & 0 & 1 & 0 \\
\hline - History of myocardial infarction & $3(2 \%)$ & 0 & 0 & 0 & 0 & 0 \\
\hline - Others & $2(1.4 \%)$ & 0 & 0 & 0 & 0 & 0 \\
\hline \multicolumn{7}{|l|}{ Pulmonary comorbidities } \\
\hline - BPCO & $3(2 \%)$ & $1(2.7 \%)$ & 0 & 0 & 0 & 1 \\
\hline \multicolumn{7}{|l|}{ Diabetes mellitus } \\
\hline - Insulin dependent & $8(5.5 \%)$ & $4(10.8 \%)$ & 1 & 1 & 3 & 2 \\
\hline - Insulin independent & $23(15.8 \%)$ & $3(8.1 \%)$ & 1 & 0 & 1 & 2 \\
\hline History of malignancy & $7(4,8 \%)$ & $10(27 \%)$ & 1 & 0 & 1 & 2 \\
\hline \multicolumn{7}{|l|}{ Jaundice } \\
\hline - At diagnosis & $107(73.8 \%)$ & 0 & 0 & 0 & 2 & 3 \\
\hline - At resection & $74(51 \%)$ & 0 & 0 & 0 & 0 & 0 \\
\hline \multicolumn{7}{|l|}{ Preoperative biliary drainage } \\
\hline - Endoscopic & $49(33.7 \%)$ & - & - & - & 2 & 2 \\
\hline - Surgical & $12(8.2 \%)$ & - & - & - & 0 & 1 \\
\hline Neo-adjuvant chemotherapy & $2(1.3 \%)$ & $3(8.1 \%)$ & 0 & 0 & 0 & 4 \\
\hline Past abdominal surgical interventions & $31(21.3 \%)$ & $10(27 \%)$ & 1 & 0 & 2 & 1 \\
\hline
\end{tabular}

cases, 2 with synthetic patch and in one case a left renal vein patch was utilized.

Inferior vena cava resection was performed in 3 cases. There was one anterior wall resection and reconstruction with a synthetic patch, one segmental resection and reconstruction

Table 3. Indications for pancreaticoduodenectomies (145 patients)

\begin{tabular}{lc}
\hline & Patients (\%) \\
\hline Pancreatic ductal adenocarcinoma & $72(49.7 \%)$ \\
\hline Distal Bile duct adenocarcinoma & $23(15.9 \%)$ \\
\hline Duodenal Adenocarcinoma & $5(3.4 \%)$ \\
\hline Malignant Ampulloma & $9(6.2 \%)$ \\
\hline Serous cystadenoma & $1(0.7 \%)$ \\
\hline IPMN & $2(1.3 \%)$ \\
\hline Solid pseuodopapillary neoplasm & $1(0.7 \%)$ \\
\hline Benign duodenal tumor & $2(1.3 \%)$ \\
\hline Neuroendocrine tumors & $6(4.2 \%)$ \\
\hline Chronic pancreatitis & $19(13.1 \%)$ \\
\hline - Groove pancreatitis & $1(0.7 \%)$ \\
\hline Metastasis & $4(2.8 \%)$ \\
\hline Associated resection &
\end{tabular}

with a vascular graft and one complex resection and reconstruction with an autologous peritoneal-fascial graft (Fig. 2).

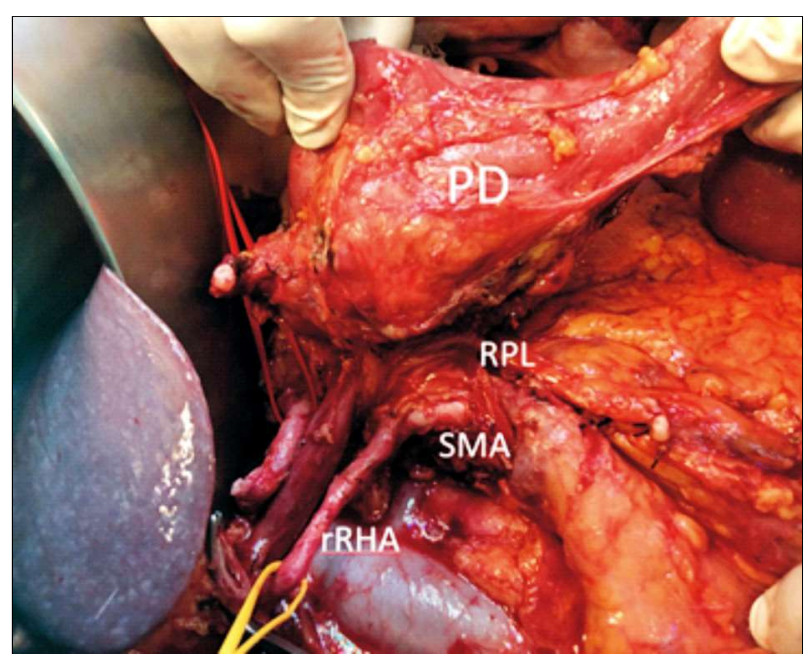

Figure 1. Intraoperative aspect from a posterior approach artery first pancreaticoduodenectomy.

PD: Pancreas and duodenum; RPL: Retro Portal Lamina;

SMA: Superior Mezenteric Artery; rRHA: replaced Right Hepatic Artery 


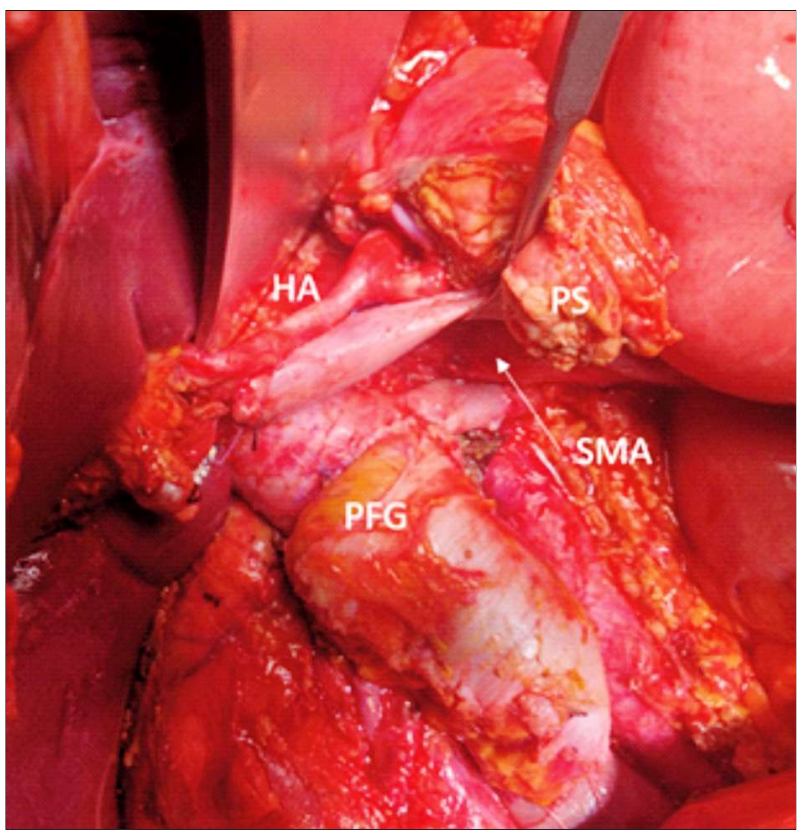

Figure 2. Intraoperative aspect after a pancreatoduodenectomy with inferior vena cava resection and reconstruction with a Peritoneal-Fascial-Graft (PFG);

PS: pancreatic stump; SMA: superior mesenteric artery, HA: common Hepatic Artery

There were 3 arterial resections, one segmental resection of the superior mesenteric artery with primary end to end anastomosis, and two replaced right hepatic arteries resection and reconstruction by end-to-end anastomosis with the gastro-duodenal artery stump (Fig. 3).

The staging for the seventy-two patients with pancreatic ductal adenocarcinoma according to the 7th edition AJCC TNM is presented in Table 4. There were 58 (80,5\%) patients with R0 resection, $13(18 \%)$ patients with $\mathrm{R} 1$ resection and one patient $(1,5 \%)$ with $\mathrm{R} 2$ resection. The number of patients with positive lymph nodes was $62(86,1 \%)$. The perineural invasion was confirmed in 70 $(97,2 \%)$ patients. The vascular invasion (16 portal-mesenteric resections, 3 arterial resections and 3 inferior vena cava resection) was confirmed in 18 patients. The resection status in the group of patients with an associated vascular resection was 19 patients with $\mathrm{R} 0$ resection and 3 patients with $\mathrm{R} 1$ resection.

The median preoperative CA 19-9 level

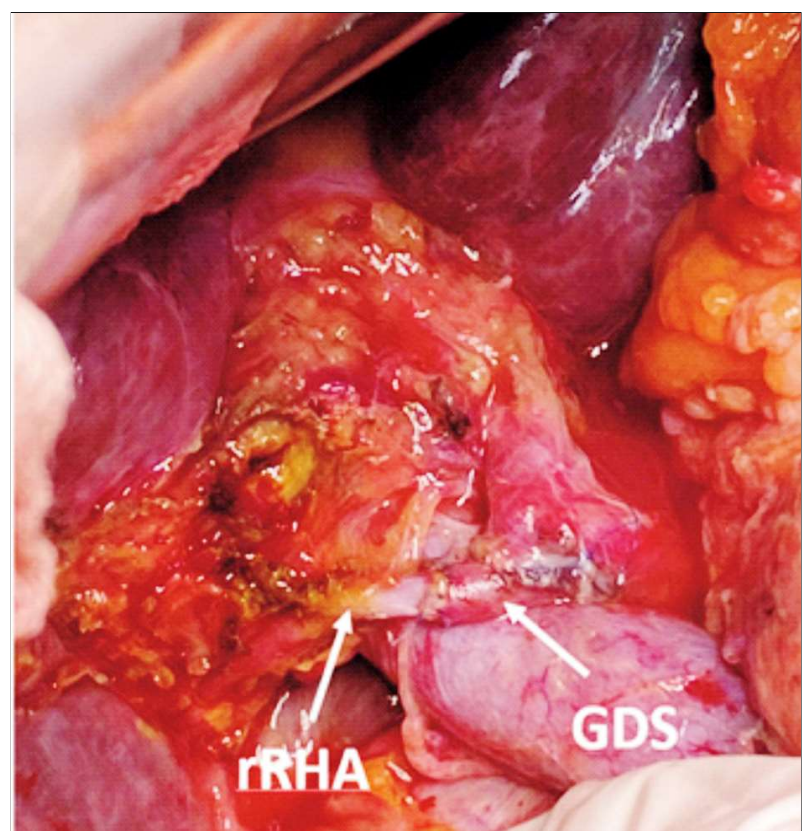

Figure 3. Intraoperative aspect from a pancreatoduodenectomy with segmental resection of a replaced right hepatic artery (rRHA) and reconstruction by end to end anastomosis with the gastro-duodenal stump (GDS)

for patients with pancreatic head ductal adenocarcinoma was $592 \mathrm{UI} / \mathrm{ml}$ (range 1 $1800 \mathrm{UI} / \mathrm{ml}$ ).

The main indications for patients with pancreaticoduodenectomy for chronic pancreatitis were highly suspicion for pancreatic cancer on preoperative imaging or inconclusive fine needle aspiration biopsy report.

In $4(2,7 \%)$ patients pancreaticoduodenectomy was performed as an associated procedure, an en-bloc resection for invasion from another organ malignancy. In this

Table 4. TNM stages for 72 patients with pancreaticoduodenectomies for pancreatic ductal adenocarcinoma ( $7^{\text {th }}$ edition)

\begin{tabular}{lr}
\hline $\mathrm{la}$ & - \\
\hline $\mathrm{Ib}$ & $4(5.6 \%)$ \\
\hline $\mathrm{Ila}$ & $6(8.3 \%)$ \\
\hline $\mathrm{Ilb}$ & $36(50 \%)$ \\
\hline $\mathrm{III}$ & $26(36.1 \%)$ \\
\hline $\mathrm{IV}$ & - \\
\hline
\end{tabular}


group, there were one patient with a distal gastric adenocarcinoma, one patient with gastric stump adenocarcinoma, one patient with recurrent anastomotic adenocarcinoma after a right hemicolectomy, and one patient with a locally advanced hepatic flexure adenocarcinoma. Pancreatic invasion was confirmed in all patients, with $\mathrm{R} 0$ resection in all cases.

Postoperative complications occurred in 94 (64.8\%) patients from the 145 pancreaticoduodenectomies. Complications are listed in Table 5 and morbidity assessed according to Clavien-Dindo in Table 6. The overall postoperative pancreatic fistula rate when we subtract the $19(13.1 \%)$ patients with biochemical leak is $22 \%$. The grade B pancreatic fistula appeared in 24 patients $(16.6 \%)$ and grade C pancreatic fistula in 8 patients $(5.5 \%)$. The delayed gastric emptying was noted in 24 patients $(16,5 \%)$. The post-pancreatectomy hemorrhage appeared in $26(17.9 \%)$ patients.

Regarding the type of resection were: 29 (20\%) patients with Whipple, 57 (39.3\%) patients with pylorus-preserving, 58 (40\%) patients with pylorus-resection and one total gastrectomy. There was no statistical significance between the type of resection and the occurrence of the delayed gastric emptying.

Regarding the pancreatic reconstruction, we performed $23(15.9 \%)$ pancreato-jejunostomies (invaginating/dunking), 73 wirsungojejunostomies and 49 (33.8\%) pancreatogastrostomies. The pancreas suture-less dunking pancreato-gastrostomy was introduced and standardized in our clinic in 2016 for the soft tissue pancreatic parenchyma with small Wirsung duct $(<3 \mathrm{~mm})$. For a more then $4 \mathrm{~mm}$ Wirsung duct a wirsungo-jejunostomy was preferred by all surgeons. The morbidity and mortality resulted from each type of anastomosis are shown in Table 7 .

Eight patients with pancreato-gastrostrostomy and post-pancreatectomy early hemorrhage (4 with $\mathrm{PPH}$ grad B and 4 with $\mathrm{PPH}$ grade $\mathrm{C}$ ) the hemostasis was obtained by upper digestive endoscopy. In another 4 patients re-laparotomy was necessary after multiple endoscopic attempts.
Table 5. Postoperative complications after pancreaticoduodenectomy (145 patients)

\begin{tabular}{lr}
\hline Postoperative pancreatic fistula: & \\
Biochemical leak & $19(13.1 \%)$ \\
Grade B & $24(16.6 \%)$ \\
Grade C & $8(5.5 \%)$ \\
\hline Delayed Gastric Emptying: & $13(9 \%)$ \\
$\quad$ Grade A & $10(6.9 \%)$ \\
Grade B & $1(0.7)$ \\
$\quad$ Grade C & $2(1,4 \%)$ \\
\hline Postpancreatectomy hemorrhage & $6(4,1 \%)$ \\
$\quad$ Grade A & $19(13,1 \%)$ \\
\hline Grade B & $6(4.13 \%)$ \\
\hline Acute postoperative fulminant pancreatitis & $17(11,7 \%)$ \\
\hline Postoperative acute pancreatitis & $16(11 \%)$ \\
\hline Intra-abdominal infection/abscess & $4(2,7 \%)$ \\
\hline Intestinal / Biliary fistulae & $1(0,7 \%)$ \\
\hline Intestinal obstruction & $3(2 \%)$ \\
\hline Pulmonary complications & $2(1,4 \%)$ \\
\hline Hepatic complications & $22(15 \%)$ \\
\hline Wound infections & $5(3,4 \%)$ \\
\hline Clostridium difficile & $2(1,4 \%)$ \\
\hline SARS CoV-2 infection & \\
\hline
\end{tabular}

Six patients with wirsungo-jejunostomy and post-pancreatectomy hemorrhage were re-operated. The bleeding sources were: pancreatic anastomosis (2 cases), gastroduodenal stump (2 cases), splenic artery ( 2 cases). Completion pancreatectectomy was performed in 2 patients and in 4 patients the Wirsung duct was drained externally.

Three patients with pancreato-jejunostomy presented grad C PPH and all required urgent re-laparotomy. The pancreatic anastomosis was the bleeding source in 2 patients and the

Table 6. Postoperative complications classified according to Calvien-Dindo in 145 patients with pancreaticoduodenectomies

\begin{tabular}{lr}
\hline Clavien-Dindo grade & Number of patients \\
\hline Grade I & $18(12.4 \%)$ \\
\hline Grade II & $24(16.6 \%)$ \\
\hline Grade IIIa & $12(8.3 \%)$ \\
\hline Grade IIIb & $16(11.0 \%)$ \\
\hline Grade IVa & $9(6.2 \%)$ \\
\hline Grade IVb & $3(2.1 \%)$ \\
\hline Grade V & $12(8.3 \%)$ \\
\hline
\end{tabular}


Table 7. Complications in relation with the type of pancreatic anastomosis patients

\begin{tabular}{lr}
\hline Pancreatico-gastrostomy & 49 \\
POPF Grade B & $12(24 \%)$ \\
POPF Grade C & $3(6,1 \%)$ \\
PPH Grade B & $4(8,1 \%)$ \\
PPH Grade C & $11(22,4 \%)$ \\
Acute postoperative fulminant pancreatitis & $2(4 \%)$ \\
Re-laparotomy & $12(24,49 \%)$ \\
Clavien-Dingo III,IV,V & $21(42,8 \%)$ \\
Deaths & $4(8,1 \%)$ \\
\hline Wirsungo-jejunostomy & 73 \\
POPF Grade B & $10(13,7 \%)$ \\
POPF Grade C & $4(5,48 \%)$ \\
PPH Grade B & $1(1,3 \%)$ \\
PPH Grade C & $5(6,8 \%)$ \\
Acute postoperative fulminant pancreatitis & $2(2,7 \%)$ \\
Re-laparotomy & $10(13,7 \%)$ \\
Clavien-Dingo III,IV,V & $12(16,4 \%)$ \\
Deaths & $7(9,59 \%)$ \\
\hline Pancreato-jejunostomy & 23 \\
POPF Grade B & $2(8,7 \%)$ \\
POPF Grade C & $1(4,3 \%)$ \\
PPH Grade B & 0 \\
PPH Grade C & $3(13 \%)$ \\
Acute postoperative fulminant pancreatitis & $1(4,3 \%)$ \\
Re-laparotomy & $5(21,7 \%)$ \\
Clavien-Dingo III,IV,V & $7(30,4 \%)$ \\
Deaths & $1(4,3 \%)$ \\
\hline
\end{tabular}

gastroduodenal stump in one. Completion pancreatectomy was performed in one patient.

Distal pancreatectomies group

In the distal pancreatectomies group, 26 $(70.3 \%)$ were standard distal pancreatectomies, $4(10,8 \%)$ were subtotal distal pancreatectomies and $7(18,9 \%)$ were caudal resections. Distal pancreatectomy with spleen preservation was performed in $8(21,6 \%)$ patients. The distal resections for pancreatic adenocarcinoma were performed by Radical Antegrade Modular Pancreatosplenectomy (RAMPS) (10) in 17 (46\%) patients and in $20(54 \%)$ by classic approach from left to right.

Portal-mesenteric vein resection was performed in $4(10,8 \%)$ patients. Segmental portal-mesenteric vein resection with primary end to end anastomosis was performed in all 4 patients. In one patient due to tumor invasion, a segmental left renal vein resection was performed with reno-cava anastomosis.

The indications for distal pancreatic
Table 8. Indications for distal pancreatic resections (37 patients)

\begin{tabular}{lr}
\hline & Patients(\%) \\
\hline Pancreatic ductal adenocarcinoma & $12(32,5 \%)$ \\
\hline Serous cystadenoma & $4(10,8 \%)$ \\
\hline Mucinous cystadenoma & $4(10,8 \%)$ \\
\hline Solid pseuodopapillary neoplasm & $2(5,4 \%)$ \\
\hline Neuroendocrine tumors & $2(5,4 \%)$ \\
\hline Chronic pancreatitis & $4(10,8 \%)$ \\
\hline Metastasis & $4(10,8 \%)$ \\
\hline Associated resection & $4(10,8 \%)$ \\
\hline Liposarcoma & $1(2,7 \%)$ \\
\hline
\end{tabular}

resections are listed in Table 8 . In $7(18,9 \%)$ patients, distal pancreatectomy was an associated procedure, an en-block resection for 3 locally advanced gastric cancer, 2 for colorectal cancer and 2 for giant retroperitoneal liposarcoma.

In $12(32,4 \%)$ of patients the distal pancreatic resection was performed for pancreatic ductal adenocarcinoma. Nine of the resections were performed by the RAMPS technique. The staging in this group of patients is summarized in Table 9. In this group of patients 3 received neoadjuvant chemotherapy. The median preoperative CA 19-9 level for patients with pancreatic head ductal adenocarcinoma was $184,7 \mathrm{UI} / \mathrm{ml}$ (range 1-1500 UI/ml).

The postoperative distal pancreatectomy fistula rate was $29,7 \%$. There were 4 bio- $^{-}$ chemical leaks, $7 \mathrm{POPF}$ and zero grade $\mathrm{C}$ POPF. Other complications were delayed gastric emptying grade $\mathrm{A}$ in 4 patients $(10,8 \%)$, and 2 patients with incisional complications $(5,4 \%)$. The mortality after distal pancreatectomy was 0 .

Distal pancreatectomy with celiac axis resection group (modified Appleby)

In our series we performed 3 distal

Table 9. TNM stages for 12 patients with distal pancreatectomy for pancreatic ductal adenocarcinoma

\begin{tabular}{lr}
\hline $\mathrm{a}$ & $1(8,3 \%)$ \\
\hline $\mathrm{Ib}$ & $1(8,3 \%)$ \\
\hline $\mathrm{lla}$ & $1(8,3 \%)$ \\
\hline $\mathrm{Ib}$ & $1(8,3 \%)$ \\
\hline $\mathrm{III}$ & $5(41,8 \%)$ \\
\hline $\mathrm{IV}$ & $3(25 \%)$ \\
\hline
\end{tabular}


pancreatectomies with celiac axis resection. In one patient the celiac truck was re-implanted into the aorta. One patient with celiac axis resection died due to liver and gastric necrosis consequence of thrombosis of the gastroduodenal artery. The indications for celiac axis resection was locally advanced pancreatic body adenocarcinoma with celiac trunk encasement in one patient, retroperitoneal lymphoma in one patient and one patient with a left suprarenal lung cancer metastasis.

Open surgery pancreatic microwave ablation group

In our series we performed 5 pancreatic microwave ablations. In 3 patients the procedure was performed for locally advanced pancreatic head adenocarcinoma after neoadjuvant chemotherapy. In one patient microwave ablation was performed for a PET positive pancreatic stump recurrence after a distal pancreatectomy.

In one patient the procedure was performed for an uncinate process neuroendocrine tumor detected at OctreoScan in a patient simultaneously operated for a lung neuroendocrine tumor.

The morbidity in this group of patients comprised of an upper digestive hemorrhage due to a pancreatic abscess that eroded into the duodenum, the patient was managed conservatively, one pancreatic abscess with liver abscess that were drained percutaneously. There was no mortality in this group of patients. From the 4 patients with pancreatic adenocarcinoma, one died more than one year after the procedure due to liver and lung metastases; the rest are still alive with no signs of recurrence.

\section{Surgery for Chronic Pancreatitis Group}

Two types of surgical interventions were carried out in patients with chronic pancreatitis. For chronic pancreatitis with no inflammatory mass in the pancreatic head and a dilated Wirsung duct (more than $6 \mathrm{~mm}$ ) we performed a Roux-en-Y jejunal limb lateral pancreaticojejunostomy (Partington-Rochelle procedure) in 2 patients. One patient developed a pancreatic grad B pancreatic fistula, an abdominal drain was left in place and removed after three weeks.

In two patients with a limited inflammatory pancreatic head mass and a moniliform dilated Wirsung duct a partial excavation of the pancreatic head combined with a lateral pancreatico-jejunostomy (Frey operation). In two patients with larger inflammatory pancreatic head mass, we performed duodenum-preserving pancreatic head resection (Beger operation) and in one patient the Berne modification of Beger procedures with the opening and inclusion into the posterior pancreatic rim of the distal common bile duct. There is no postoperative mortality in this group of patients.

Analysis of Survival for 85 patients with pancreatic ductal adenocarcinoma (72 pancreaticoduodenectomies, 12 distal pancreatectomies and 1 Modified Appleby).

The median overall survival for patients with resected for pancreatic adenocarcinoma was 16 months. The estimated overall 1,3 and 5-year survival rate was $65,2 \%, 15 \%$ and $10 \%$.

For patients with negative lymph nodes the median overall survival was 26 months and for positive lymph nodes patients the median overall survival was 13 months (Log Rank $\mathrm{p}=0.039$ ). In patients with negative resection margins the median overall survival was 17 months and 11 months in patients with a positive margin ( $\log$ Rank $\mathrm{p}=0.039$ ). The Kaplan-Mayer survival estimation is presented in Fig. 4.

The in-hospital mortality for pancreaticoduodenectomy group was $8,3 \%$. The 90-day mortality was $9,6 \%$.

\section{Discussions}

This study presents our department's experience in pancreatic resections over the last 6 years. The number of pancreatic resections has been increasing from only 10 in 2014, 30 in 2018 to 50 in 2019. The Leapfrog Group's standard for evidence-based patient hospital referral recommends a minimum volume of more than 10 cases per year for pancreatic resections (11). Taylor S Riall et all suggested 

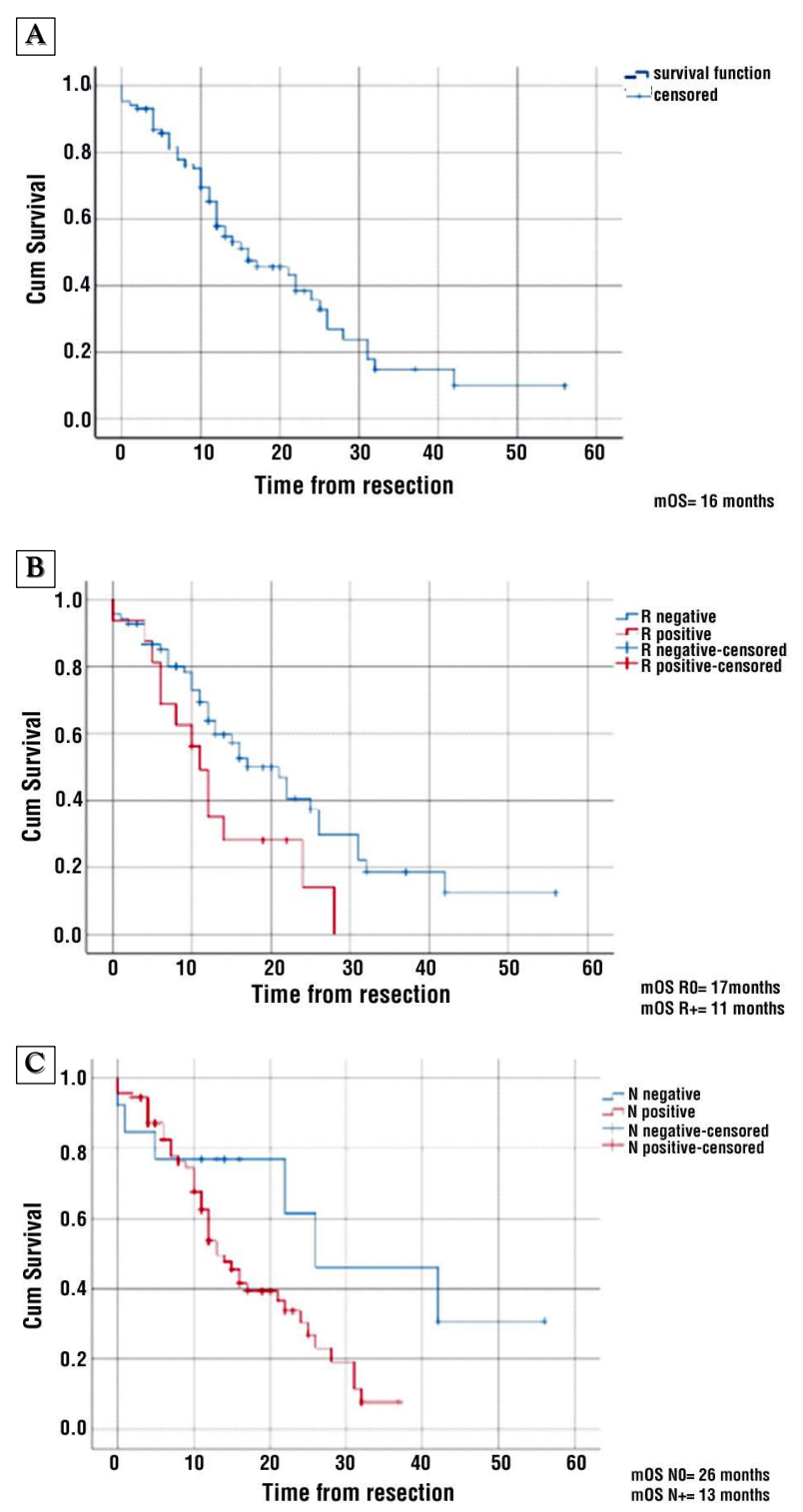

Figure 4. Kaplan-Mayer survival curves in 85 patients with pancreatic ductal adenocarcinoma. (A) overall survival. (B) Resection status, negative and positive margins. (C) Lymph node negative and positive patients

that the measurement of a hospital volume is no a reliable single measure of quality or outcomes after pancreatic surgery (12). However, institutions with greater than 20 pancreatic resections per year demonstrated improved survival over lower volume center $(13,14)$. Despite the pandemic context of the current year, our department surpassed the cut-off point of more the 20 pancreatic resection per year, with 28 pancreatic resections until October 2020.
In 2016 a national intent electronic registry, initially only for pancreaticoduodenectomies, was proposed for all Romanian surgical centers at the initiative of two high volume centers. The results after the first year of enrollment have been published in 2018 (15). Initially, there were 3 centers who enrolled patients, our department being one of them. At the moment five Romanian surgical departments are enrolling patients to the national pancreatic resections database. The total number of patients until October 2020 are: 651 pancreaticoduodenectomies (86 from our department), 165 distal pancreatectomies (31 from our department), 31 total pancreatectomies ( 1 from our department). The registry is opened for all Surgical Departments performing pancreatic surgery.

Several issues about the practice and outcomes in this series of patients with pancreatic resections should be discussed. The concept of posterior approach pancreaticoduodenectomy with total mesopancreas excision has become standard of care in many surgical centers (16). In our series in 105 patients the pancreaticoduodenectomy was performed by posterior approach artery first. This approach was first described in 2006 by Pessaux et all (17) and in 2007 by Popescu et all (18) reported a technical version and preliminary outcomes. Since then, many other artery-first approaches were described and have become standard techniques in pancreatic surgery, not only for pancreaticoduodenectomies but also for distal pancreatectomies (19-21). The posterior approach has been shown to decrease the intraoperative bleeding and operative time (22). A meta-analysis published in 2018 by Ironside et all comparing artery-first approach versus standard approach pancreaticoduodenectomy on perioperative outcomes and survival found that the artery first approach may be associated with improved perioperative outcomes and survival, but Clavien-Dindo grade III or more morbidity showed no significant difference between the two groups (23). The artery first approach is associated with reduced overall morbidity, but this may be secondary to reduced intraoperative blood loss 
and transfusion requirements, risk factors for postoperative complications (24).

Regarding the type of reconstruction after pancreaticoduodenectomy and the treatment of the pancreatic stump, in our series we have $49(33.8 \%)$ patients with pancreatogastrostomy.

From 2016 the reconstruction technique has been standardized in our department. For the soft tissue pancreas with a small duct or for patients which are considered at high risk for postoperative complications (age, obesity, cardiovascular disease, diabetes mellitus) we perform a pancreas suture-less invaginating pancreato-gastrostomy. The technique consists of mobilization of the pancreatic body for 4-5 cm, a posterior gastrostomy with half the diameter of the pancreatic body. A seromuscular continuous PDO 3.0 purse around the posterior gastrostomy and the pancreas is brought into the gastric lumen by and anterior gastrotomy when pylorus preservation or pylorus resection is performed. We routinely place a pancreatic stent whenever the Wirsung duct is found. This technique is simple, reproducible and quick to perform and we believe it has the lowest potential of traumatizing a high-risk pancreas by suture injury $(25,26)$. Although this type of anastomosis did not reduce the incidence of the postoperative pancreatic fistula, it reduced the re-laparotomy rate for early bleeding. One explanation for this is that in the majority of patients with postoperative early bleeding, the bleeding source was at the level of the pancreatic stump, which could be controlled by endoscopic hemostasis. Re-laparotomy was performed when bleeding appeared due to septic complications, usually a peripancreatic abscess, in many cases the bleeding source being a major vessel.

The majority of post-operative pancreatic fistulas (POPH) after this type of anastomosis were classified as biochemical leaks, having no impact on the postoperative course. For type B $\mathrm{POPH}$ an abdominal drain was left in place until the fistula self-resolved, usually more than 2-3 weeks. All the type B POPH that complicated with hemorrhage or septic complications that needed urgent re-laparotomy or when endoscopic or percutaneous interventions failed, were classified as type C POPH. Although there is conflicting evidence regarding the best reconstruction method for the pancreatic stump after pancreaticoduodenectomy (27) we believe that this type of anastomosis for the high-risk soft tissue pancreas can be associated with less severe postoperative complications.

Our overall POPF grade B/C rate was $22 \%$ and the all grades PPH incidence was $17.9 \%$. These results are similar to a prospective multicenter randomized control trial comparing pancreatogastrostomy to pancreatojejunostomy from 14 high volume academic centers for pancreatic surgery, with a grade B/C POPH of $21 \%$ and overall PPH of $17 \%$. The authors also conclude that perioperative morbidity and mortality seem to be underestimated, even in high-volume centers (28).

The main goal of associating vascular resections is to obtain negative resection margins. Although portal vein and superior mesenteric vein resections have been proven to be technically feasible, venous resection is associated with high postoperative complication rates and mortality (29). In our series of 145 pancreaticoduodenectomies vascular resections were performed in 22 patients, there were 16 portal-mesenteric vein resections, 3 inferior vena cava resections and 3 arterial resections. The vascular invasion was confirmed at the final pathologic examination in 18 patients. The arterial resections were performed for two replaced right hepatic arteries, which were anastomosed with the gastro-duodenal stump and one superior mesenteric artery segmental resections with end-to end anastomosis. It is worth mentioning, from the three patients with pancreaticoduodenectomy and inferior vena cava resection, the inferior vena cava reconstruction was performed by an autologous peritoneal-fascial graft. Figure2. To the best of our knowledge, this is the first case in the Romanian literature.

Among the 145 patients with pancreaticoduodenectomies, 72 patients were operated for pancreatic ductal adenocarcinoma. The majority of the patients, $36(50 \%)$ were staged 
as IIb on the final pathologic examination. The R0 resection status was confirmed in 58 $(80.5 \%), \mathrm{R} 1$ in $13(18 \%)$ patients and one patient with R2. The resection status after pancreaticoduodenectomy for pancreatic head adenocarcinoma is an independent risk factor for overall survival (30), as shown in our series, patients with a positive resection margin had a worst overall survival. Regarding the final pathologic examination, it is worth mentioning that our pathology department has a single dedicated team specialized in the management of pancreatic resection specimens with a standardized protocol with international support and (31). It has been shown that the technique of lymph node harvesting used by the pathologist may have an impact on the number of lymph nodes examined with important consequence on the staging of the patient (32). The same applies to the resection status after pancreaticoduodenectomy. Without applying a standardized protocol, the $\mathrm{R} 1$ resection rate is around $14 \%$, but when a standardized protocol is systematically applied the $\mathrm{R} 1$ rate can reach $76 \%$ (33).

Regarding the low median overall survival of 16 months in patients with pancreatic ductal adenocarcinoma, we have to mention the relatively high number of patients with positive lymph nodes in our series. In patients with pancreatic head adenocarcinoma $86.1 \%$ (62/74) were lymph node positive and in patients with distal pancreatic adenocarcinoma $66.6 \%(8 / 12)$ had positive lymph nodes. The low median overall survival is explained by the high number of positive lymph nodes which explains the aggressive nature of this type of cancer.

One of the limitations of our analysis is that in our database the patients were introduced in a prospectively manner from 2016, the moment the national pancreatic resection registry was formed and we started to include all the patients. Before 2016 the date was gathered from hospital records, with known limitations and implications.

\section{Conclusions}

Pancreatic surgery continues to remains a challenge for every team dedicated in the treatment of these patients. Not only the state-of-the-art diagnostic possibilities or meticulous surgical technique contributes to postoperative outcomes, but also the possibilities in treating complications by minimally invasive approaches: percutaneously, endoscopic or angiographic.

We presented our department's experience in pancreatic surgery with good overall results, however, there is still room for continuous improvement and refinements to achieve better short-term outcomes.

By continuously enrolling patients to the National Pancreatic Resection Registry in a transparent approach, we hope not only to encourage other surgical centers to participate with their own experience, but also to improve the national outcome after this type of surgery.

\section{Conflicts of Interest: None}

\section{Ethics Approval}

For performing this study ethical approval was obtained.

\section{References}

1. Baker EH, Siddiqui I, Vrochides D, Iannitti DA, Martinie JB, Rorabaugh L, et al. Building the Nonuniversity, Tertiary Care Center Hepatobiliary and Pancreatic Surgery Practice: Structural and Financial Considerations. Am Surg. 2016;82(12):1196-202.

2. Schnelldorfer T, Adams DB, Warshaw AL, Lillemoe KD, Sarr MG. Forgotten Pioneers of Pancreatic Surgery: Beyond the Favorite Few. Ann Surg. 2008;247(1):191-202.

3. Schnelldorfer T, Sarr MG. Alessandro Codivilla and the First Pancreatoduodenectomy. Arch Surg. 2009;144(12):1179.

4. Griffin JF, Poruk KE, Wolfgang CL. Pancreatic cancer surgery: past, present, and future. Chin J Cancer Res. 2015;27(4):332-48.

5. Popescu I, Dumitrascu T. Pancreatoduodenectomy--past, present and future. Chirurgia (Bucur). 2011;106(3):287-96.

6. Pulvirenti A, Ramera M, Bassi C. Modifications in the International Study Group for Pancreatic Surgery (ISGPS) definition of postoperative pancreatic fistula. Transl Gastroenterol Hepatol. 2017; 2(12):107-107

7. Wente MN, Veit JA, Bassi C, Dervenis C, Fingerhut A, Gouma DJ, et al. Postpancreatectomy hemorrhage (PPH)-An International Study Group of Pancreatic Surgery (ISGPS) definition. Surgery. 2007; 142(1):20-5 
8. Wente MN, Bassi C, Dervenis C, Fingerhut A, Gouma DJ, Izbicki JR, et al. Delayed gastric emptying (DGE) after pancreatic surgery: A suggested definition by the International Study Group of Pancreatic Surgery (ISGPS). Surgery [Internet]. 2007;142(5):761-8.

9. Dindo D, Demartines N, Clavien P-A. Classification of Surgical Complications: A New Proposal With Evaluation in a Cohort of 6336 Patients and Results of a Survey. Annals of Surgery. 2004; 240(2):205-13.

10. Strasberg SM, Drebin JA, Linehan D. Radical antegrade modular pancreatosplenectomy. Surgery. 2003;133(5):521-7.

11. Birkmeyer JD, Dimick JB. Potential benefits of the new Leapfrog standards: effect of process and outcomes measures. Surgery. 2004;135(6):569-75.

12. Mehta HB, Parmar AD, Adhikari D, Tamirisa NP, Dimou F, Jupiter D, et al. Relative impact of surgeon and hospital volume on operative mortality and complications following pancreatic resection in Medicare patients. J Surg Res. 2016;204(2):326-334.

13. Briceno P, Huston J, Shridhar R, Meredith K. Pancreatic resection at high volume centers improves survival. HPB. 2017;19:S171.

14. Fong $\mathrm{Y}$, Gonen M, Rubin D, Radzyner M, Brennan MF. Long-Term Survival Is Superior After Resection for Cancer in High-Volume Centers. 2005;242(4):540-547.

15. Bartos A, Ionescu M, Iancu C, Stroescu C, Zaharie F, Brasoveanu V, et al. An Attempt to Build a National Prospective Electronic Database for Pancreaticoduodenectomies in Romania - Preliminary Results of the First Year Enrollment. Chirurgia (Bucur). 2018; 113(3):374-384

16. Popescu I, Dumitrascu T. What is the Value of Total Mesopancreas Excision in Pancreatic Ductal Adenocarcinoma? Current Evidence of the Literature. Chirurgia (Bucur). 2018;113(3):335-343.

17. Pessaux P, Varma D, Arnaud J. Pancreaticoduodenectomy: superior mesenteric artery first approach. J Gastrointest Surg. 2006; 10(4):607-11.

18. Popescu I, David L, Dumitra A-M, Dorobantu B. The posterior approach in pancreaticoduodenectomy: preliminary results. Hepatogastroenterology. 2007;54(75):921-6

19. Weitz J, Rahbari N, Koch M, Büchler MW. The "artery first approach for resection of pancreatic head cancer. J Am Coll Surg. 2010;210(2):e1-4. Epub 2009 Dec 3.

20. Sanjay P, Takaori K, Govil S, Shrikhande SV, Windsor JA. "Arteryfirst" approaches to pancreatoduodenectomy. Br J Surg. 2012 99(8):1027-35.

21. Takaori K, Uemoto S. Artery-First Distal Pancreatectomy. Dig Surg. 2016;33(4):314-9.

22. Dumitrascu T, David L, Popescu I. Posterior versus standard approach in pancreatoduodenectomy: a case-match study.
Langenbecks Arch Surg. 2010;395(6):677-84.

23. Ironside N, Barreto SG, Loveday B, Shrikhande SV, Windsor JA, Pandanaboyana S. Meta-analysis of an artery-first approach versus standard pancreatoduodenectomy on perioperative outcomes and survival. Br J Surg. 2018;105(6):628-36.

24. Pandanaboyana S, Loveday B, Windsor JA. Artery First Approach to Pancreatic Cancer Resection: A Review of the Evidence for Benefit. JOP J Pancreas. 2017;18(5):369-72.

25. Peng S, Hong D, Liu Y, Li J, Tao F, Tan Z. A pancreas suture-less type II binding pancreaticogastrostomy. Zhonghua Wai Ke Za Zhi. 2009:47(23):1764-6.

26. Kostov D, Kobakov G, Yankov D. Pancreatogastrostomy with one continous seromuscular circular suture. IJSM. 2015;1(1):2.

27. Cheng $\mathrm{Y}$, Briarava $\mathrm{M}$, Lai $\mathrm{M}$, Wang $\mathrm{X}, \mathrm{Tu} \mathrm{B}$, Cheng $\mathrm{N}$, et al. Pancreaticojejunostomy versus pancreaticogastrostomy reconstruction for the prevention of postoperative pancreatic fistula following pancreaticoduodenectomy. Cochrane Database Syst Rev. 2017; 2017(9): CD012257.

28. Keck T, Wellner UF, Bahra M, Klein F, Sick O, Niedergethmann M, et al. Pancreatogastrostomy Versus Pancreatojejunostomy for RECOnstruction After PANCreatoduodenectomy (RECOPANC, DRKS 00000767): Perioperative and Long-term Results of a Multicenter Randomized Controlled Trial. Ann Surg. 2016;263(3): 440-449.

29. Dumitrascu T, Martiniuc A, Brasoveanu V, Stroescu C, David L, Dima $S$, et al. One Hundred Pancreatectomies with Venous Resection for Pancreatic Adenocarcinoma. Chirurgia (Bucur). 2018;113(3):363-373

30. Li C-G, Zhou Z-P, Tan X-L, Gao Y-X, Wang Z-Z, Liu Q, et al. Impact of resection margins on long-term survival after pancreaticoduodenectomy for pancreatic head carcinoma. WJCC. 2019;7(24): 4186-95.

31. Adsay NV, Basturk O, Saka B, Bagci P, Ozdemir D, Balci S, et al. Whipple Made Simple For Surgical Pathologists: Orientation, Dissection, and Sampling of Pancreaticoduodenectomy Specimens For a More Practical and Accurate Evaluation of Pancreatic, Distal Common Bile Duct, and Ampullary Tumors. The American Journal of Surgical Pathology. 2014;38(4):480-93.

32. Adsay NV, Basturk O, Altinel D, Khanani F, Coban I, Weaver DW, et al. The number of lymph nodes identified in a simple pancreatoduodenectomy specimen: comparison of conventional vs orangepeeling approach in pathologic assessment. Mod Pathol. 2009; 22(1):107-12.

33. Esposito I, Kleeff J, Bergmann F, Reiser C, Herpel E, Friess H, et al. Most Pancreatic Cancer Resections are R1 Resections. Ann Surg Oncol. 2008;15(6):1651-60. 